This item was submitted to Loughborough's Research Repository by the author.

Items in Figshare are protected by copyright, with all rights reserved, unless otherwise indicated.

\title{
Social change and progress in the sociology of Robert Nisbet
}

PLEASE CITE THE PUBLISHED VERSION

http://dx.doi.org/10.1007/s12115-015-9908-0

\section{PUBLISHER}

Springer

\section{VERSION}

AM (Accepted Manuscript)

\section{PUBLISHER STATEMENT}

This work is made available according to the conditions of the Creative Commons Attribution-NonCommercialNoDerivatives 4.0 International (CC BY-NC-ND 4.0) licence. Full details of this licence are available at: https://creativecommons.org/licenses/by-nc-nd/4.0/

\section{LICENCE}

CC BY-NC-ND 4.0

\section{REPOSITORY RECORD}

Chernilo, Daniel. 2019. "Social Change and Progress in the Sociology of Robert Nisbet". figshare. https://hdl.handle.net/2134/17781. 


\title{
Social Change and Progress in Robert Nisbet ${ }^{*}$
}

\author{
Daniel Chernilo* \\ (forthcoming in Society 2015)
}

Robert Nisbet is an unconventional figure in twentieth-century American sociology. Quite rightly, his name is firmly associated with the development of a clear disciplinary canon and a systematic understanding of sociology's intellectual past and main traditions; a canon that goes also beyond sociology's alleged ideological divide between Marxist and bourgeois approaches (Bottomore and Nisbet 1978). ${ }^{1}$ He declared openly to be a conservative (Nisbet 1988), was self-confessedly more parochial than international or cosmopolitan in upbringing and outlook (Nisbet 1986), his was work was more of an historicist bent than either strictly theoretical or empirical (Nisbet 1976), and he was systematically more interested in sociology's moral texture than in its scientific operation (Nisbet 1977). Thus, when at the beginning of The Sociological Tradition Nisbet offers an account of the rise of sociology, it is arguably the case that his claims describe better his own perplexing position within American sociology than the actual development of the discipline: sociology's 'creative paradox', he says, 'lies in the fact that although it falls, in its objectives and in the political and scientific values of its principal figures, in the mainstream of modernism, its essential concepts and its implicit perspectives place it much closer, generally speaking, to philosophical conservatism' (Nisbet 1967: 17).

All four features - conservatism, parochialism, historicism and the moral texture of sociology - become apparent in Nisbet's work on the ideas of progress and social change that constitute my focus in this piece. Progress and social change are among sociology's key notions, they are central to sociology's modernist outlook and are thus commonly understood in positive terms. Again in this case, Nisbet is partly within conventional sociological terrain. Alongside several towering figures of mid twentieth-century American sociology - Reinhard Bendix (1970) Robert Merton (1968), Talcott Parsons (1971) and Edward Shils (1980) - Nisbet was deeply interested in these concepts and his work on them expanded for well over three decades. ${ }^{2}$ But then Nisbet is very much on his own within sociology in his sceptical attitude to these notions and their wider cultural

\footnotetext{
* My thanks to Peter Baehr, Rodrigo Cordero, Robert Fine and Bryan S. Turner for valuable comments and bibliographical references.

** Reader in Social and Political Thought, Loughborough University, UK. Email: D.Chernilo@lboro.ac.uk

1 As an undergraduate student immediately after the end of Pinochet's dictatorship in Chile in the early 1990s, the Spanish edition of this companion was still the book which we studied the origins of sociology.

2 Outside the US, this would apply also to Raymond Aron (1972) in France and Morris Ginsberg (1965) in the UK.
} 
implications. The criticisms he raised against the way in which modern sociology and indeed modern society itself have understood progressive social change were rather unique within the sociological mainstream to which he nonetheless belonged.

But at the same time as his outlook can be seen as highly original inside sociology, it is worthy of note that similar arguments were readily available in other disciplinary and intellectual traditions. There were, of course, the criticisms of modern ideas of progress that, between the 1940s and the 1960s, were being offered by Jewish German émigrés on the left - say, in the works of Benjamin, Adorno and Horkheimer, Marcuse or Fromm. But there was also a 'conservative' group of scholars who were indeed of the same generation and background as the critical theorists but had developed their own critique of progress. Karl Löwith, Leo Strauss and Eric Voegelin, to mention only three salient cases, were also German émigrés in America who made the shaky foundations and thorny implications of modern ideas of progress and social change central to their own intellectual work. The three of them wrote a book on exactly these questions and at the same time: Meaning in History was first published in 1949 (Löwith 1964), Natural Right and History in 1950 (Strauss 1970) and The New Science of Politics in 1952 (Voegelin 2000). Nisbet however did not engage with any of these works.

In what follows, I should like to proceed in three steps. First, I reconstruct the central tenets of Nisbet's conceptions of social change, history and progress; secondly, I revisit his analysis of the rise of modern social institutions in America as an empirical application of sociology's key distinction between community and society; thirdly, I compare Nisbet's arguments as they unfold in those two sections with the central tenets of Löwith and Strauss's critique of modern thought.

I.

One of Nisbet's main contentions in his long durée approach to intellectual history is that metaphors are a central cognitive resource with the help of which human beings try to grasp the enormous complexity of natural and social life. Metaphors have been a privileged strategy for dealing with social change throughout human history and are indispensable from our generic human capacity to make sense of complicated or unpredictable sequences of events. At the same time, however, the use of metaphors brings with it the risk of mistaking our intellectual tools for 'the real thing', and that is exactly what happened at the onset of modernity: ' $[t]$ o look at the whole universe and say it is like a machine or organism is one thing: forgivable in proper time and place. But to seek to build rigorous propositions of scientific analysis upon either metaphor, mistaking attributes of analogy for attributes of reality, can be, as the history of science teaches us, profoundly limiting and distorting' (Nisbet 2009: 6-7). We immediately encounter some of Nisbet's recurrent themes: the assessment of 
continuities and discontinuities between premodern and modern, religious and secular, forms of thinking; the relationships between metaphors and analogies, and the extent to which the hypostatisation of novelty, internal coherence and causal necessity is a major feature of modernist thinking in general.

Nisbet then highlights the importance of distinguishing between the idea of social change, which is ubiquitous in history, and notions of progress, evolution and development, which are particularly Western and modern. Change is a fundamental feature of the cosmos and Nisbet contends that ideas growth and even progress are readily available to the senses as we attempt to figure out what is happening in the natural world. The idea of growth is indeed central to Greek classical philosophy, where it refers to the ultimate nature of things, and has since remained a major if not the major metaphor of Western thought (Nisbet 1986: 85, 2009: 8-23, 140). Indeed, the Greek notion of physis points to the intrinsic pattern of growth through which everything that exists in the universe moves towards the fulfilment of its intrinsic ends. To the extent that the Greeks distinguished at all between a natural and a social domain as two separate ontological realms, their way of drawing that distinction was of course different from the modern one; yet the fact remains that we require a clear definition of the unit that is being described as undergoing growth or change. The teleological approach that underpins the Greek ontology of the physical world was equally being applied to human entities: it referred to plants as well as cultures, to animal species as well as to the polis and humankind as a whole. The holistic conceptions of change of premodern times required that all cases that belonged to the same group were by definition subject to the same rules because they were similar in nature; in turn, this is how relevant units or domains became clearly identifiable. $^{3}$

A similar argument can be used to ascertain Nisbet's idea of history. He suggests that 'the distinction between history and development is a subtle one at best', but he nonetheless tries to separate between the two in Western philosophy (Nisbet 2009: 72). He again traces this back to classical Greece, where there is a first sense of history that he refers to the 'historian's past'; this is a kind of historiography that concerns itself with particular persons, events and happenings. But there is also a second, strictly developmental, idea of history whose focus lies explicitly on change (rather than events) and that looks for underlying causes (rather than for particular facts, Nisbet 2009: 30-2). Thucydides, Ranke or Mommsen are to Nisbet salient representatives of the first approach, while the second has become

3 This fascination with self-contained units and discrete wholes is in his view a constitutive feature of the intellectual imagination of Western civilisation (Nisbet 2009: 24, 45, 249-50; 1976: 433-4; 1988: 70). In modernity, this is arguably best represented in the understanding of nation-states as self-contained and self-sufficient units - a debate that recently has cohered on the problem of so-called 'methodological nationalism' (Chernilo 2007, 2011). 
by far the dominant trend in Western historical thinking from Augustine to Comte via Hegel. Indeed, even as he credits Aristotle as a potential model for both ideas of history, Nisbet argues that, at the end, a cyclical conception of change remains Aristotle's true 'framework of methodology' (Nisbet 2009: 40).

As a developmental approach to history becomes more and more prevalent, the most consequential transformation takes place within Christian philosophy: cyclical patterns of growth and decline become increasingly abandoned and get replaced by a new sense of linear development that is to be seen as progress. Augustine is of course a major player in this narrative, but Nisbet (1980: 140-5) credits above all Jacques-Bénigne Bossuet (1627-1704) for this transition. Bossuet's Discourse on Universal History, written as it was from a Catholic perspective, laid the ground for most of the traits that have since become central to modern developmental approaches in the social sciences: a clearly set our rationale for the whole of the historical process, a discrete and logical progression between epochs, and the idea that, in addition to particular nations, empires or even religions, true history can only be written as world or universal history. ${ }^{4}$ The early idea of physis as the necessary movement towards the fulfilment of any unit's intrinsic properties then becomes transformed, in the seventeenth century, into an idea of natural history that is to account for the unfolding of these constitutive properties over time (Nisbet 2009: 143). ${ }^{5}$ As such, natural history was deemed superior, more scientific, than 'conventional' history that remained only concerned with dates or heroic individuals. We must, to be sure, accept the 'irreversible quality of history' as there is just no going back in time (Nisbet 1967: 296). And even as he remains deeply sceptical of developmental history, he equally accepts that the more traditional approach to history that simply searches for the right dates is, or has become, 'probably futile' (Nisbet 2009: 31). In a way that we shall see below resembles his wider assessment of twentieth-century American society, Nisbet writes that the contemporary teaching and practice of history is in a dire state because the very sense of what history is, why is history at all relevant, has become lost: 'the past in any meaningful sense has been almost obliterated' (Nisbet 1980: 328).

Traditional ideas of change, both natural and social, have therefore clear developmental side to them and to that extent the modern idea of progress needs to be traced back to the origins of Western civilisation itself (Nisbet 1980). Indeed, developmentalism itself 'long preceded' nineteenth-century 'biological evolution in having respectability in philosophy' (Nisbet 2009: 26). In other words, the belief in the immanent development of everything that exists - the

\footnotetext{
${ }^{4}$ Karl Löwith (1964: 137-44) also discusses Bossuet's work in this context and although he offers a similar interpretation to Nisbet of this book, Löwith is less impressed by the novelty of Bossuet's approach to universal history.

${ }^{5}$ On seventeenth-century intellectual developments that gave rise the rise of the modern Weltanschauung, see Toulmin (1990), Hochstrasser (2000).
} 
elements, a human being, a political community - towards the fulfilment of its own intrinsic ends is a philosophical argument that predates modern science; it is a key presupposition of the Western philosophical tradition rather than a modern or scientific one. There is however one central belief of classical conceptions of growth that is fundamentally different from those we find in modernity: while in both cases growth is inscribed in nature, it is only in modernity that growth becomes progressive, inevitable, sequential and permanent. Differently put: if growth becomes our speculative starting point, then decline is as logical a possibility as progress - and indeed, if we look at the historical record of Ancient civilisations, for instance, decay it is even more likely than progress or growth. Traditional conceptions of cyclical time are therefore not only compatible with the classical ontology of growth but may actually be a better fit for it than modern evolutionism because they allow also for decay.

Nisbet's reconstruction of the modern idea of progress understood as social evolution includes six key components. It is: (1) natural, insofar as transformations over time are bound to occur; (2) directional, whereby the succession of stages leads necessarily to a final stage or goal; (3) immanent, because change occurs within the unit and as a result of the unit's internal properties; (4) continuous, as there is a logical sequence between past, present and future within any single series of events; (5) necessary, because there is complete synchronicity between the structural properties of the unit and its various changes, and (6) uniform, because it is expected that similar causes ought to trigger similar consequences (Nisbet 2009: 166-88). Whilst some of these features appear in premodern conceptions of growth, Nisbet fundamentally objects to the false sense of consistency and necessity that emerges as these are put together as a question of principle.

Another way of making this argument is that, whereas modern conceptions of growth as progress appear to be based on purely immanent factors, this is not in fact the case because, logically speaking, the idea of immanence presupposes some 'external' limit that becomes its own version of the transcendental. In order to work as a framework that can actually orient human action, some kind of telos must remain elusively transcendental. This is indeed one key feature of modern evolutionism in the social sciences: through its account of the biological underpinnings of all human action and evolution, it offers a natural framework within which to locate all sociocultural developments; while the latter can be modified and are indeed highly variable (i.e. they are immanent), the former is understood as a constant make up of our species that is resistant to social intervention (human nature cannot be changed at will and so it remains quasitranscendental). ${ }^{6}$ All empirical discoveries about social action are the result of the

${ }^{6}$ Although it has not always made consistent use of this insight, functionalist sociology has understood this better than any other sociological tradition: see, paradigmatically, 
human capacity to use our reason; our understanding of the natural world is a strictly rational or scientific achievement and does not depend on divine revelation. But the ability to transform our 'humanity' remains at least partly transcendental because 'human nature' is never readily open to deliberate manipulation: however much it may change thanks to technological innovations, there are still 'limits' on what we are able to achieve (and may possibly want) as members of this particular mammal species. ${ }^{7}$

If we now turn to the question of Nisbet's 'methodology' for looking at the history of ideas, we can use the following quotation to appreciate in detail how Nisbet formulates this argument:

For twenty-five hundred years a single metaphoric conception of change has dominated Western thought. Drawn from the analogy between society and the organism, more specifically between social change and the lifecycle of the organism, this metaphor very early introduced into Western European philosophy assumptions and preconceptions regarding change in society that have at no time been without profound influence on Western man's contemplation of past, present and future. In its earliest formulation, in Greece, the metaphor and analogy produced the idea of recurrent cycles of development. It was an idea that went unchallenged for a thousand years. Then in the fifth century A.D. St. Augustine, without abandoning the analogy, modify it; and from his modification came the momentous Christian envisagement of change that we call the epic, which cyclical like the Greek doctrine from which it was drawn but without recurrence. Twelve hundred years passed, and in the seventeenth century the analogy, still popular, was again modified; this time to produce the modern idea of linear progress; the vision of mankind without the old age of decline, with ever-increasing knowledge ahead (Nisbet 2009: 211-2, my italics $)^{8}$

There are several issues that are worth highlighting here:

(1) While in Antiquity cycles were understood to have repeated themselves, the key transformation that was elicited by Christian philosophy, and which was

Parsons's (1967) theory of the evolutionary universals in society and Luhmann's (1977) discussion of symbolic and symbiotic mechanisms.

7 See Bendix (1970) for an insightful analysis of the relationships between social life and human nature in sociology. More recently, Luc Boltanski's (2013) work on reproduction and abortion offers a reflection on the social and natural sources of our shared humanity. Partially modelled on the twentieth-century programme of philosophical anthropology, these questions are also central to the research programme that, following Löwith, I have called philosophical sociology (Chernilo 2014). See note 16 below.

8 Similar arguments are made repeatedly in the book (Nisbet 2009: 35, 38, 63, 88, 96-7). 
then adopted in modern times, was that history moves in a progressive trajectory that is depicted as unique and directed to the fulfilment of its own pre-inscribed ends (Nisbet 2009: 70-1). In its strictly modernist version, whereby social change is understood as secular progress, development or evolution, the present is now regarded as inherently and necessarily superior to the past whilst it remains inferior vis-à-vis the projected future (Nisbet 2009: 47).

(2) The seventeenth century is treated as the critical period in which the major cosmological transformations of modern thinking took place. From now own, the question about the existence of a 'transcendental' realm that is open to 'divine' intervention is left answered, whilst at the same time it is increasingly accepted that a true scientific outlook can legitimately concentrate on only three 'immanent' domains: the natural world, individual psychology and history (or society): these three alone are susceptible to rational, indeed empirical, research. Moreover, as the rise of sociology itself makes apparent, a strictly 'social' realm begins to achieve its increasing autonomy (Nisbet 2009: 89, 107-8). This is the key moment of 'secularisation' whereby divine forces are no longer allowed to intervene in human and natural history: earthquakes and famines are to be explained with regards to the earth's properties, climate, agricultural techniques or even irrational patterns of consumption but not in relation to God's will. The modern idea of progress is immanent because although it presupposes a transcendental goal as the end of history, the path to achieve that goal is supposed to be populated only by immanent (i.e. natural, social, historical or individual) causes that can be accounted for empirically.

(3) I chose to highlight Nisbet's use of 'metaphor' and 'analogy' in the long quotation above because it seems to me that he does not distinguish adequately between the two: metaphors are as a generic human capacity to make symbolic representations of events that appear to have a hidden meaning. Analogies, for their part, are a more specific way of making logical inferences from evens that take place in one realm (say nature) to what may be taking place in others (say society): analogies can indeed be used metaphorically but do not have to. Analogies point to the direct and explicit possibility of extrapolating knowledge from one ambit onto a different one in terms of logical comparisons, a sense of proportion, and corresponding features; metaphors, for their part, only do this indirectly and rhetorically. To that extent, analogical reasoning is central to modern scientific thinking in a way that metaphors are not; analogies are welcome and explicitly pursued in scientific work because they allow for analytical precision while metaphors are more poetic and seek to create a sense of the bigger picture. See, on this question, the following formulation:

I am not suggesting that the modern idea of progress is the same as either the Christian epic or the classical cycle (...) But it is surely of more than merely antiquarian interest that this modern idea of progress, with all its 
differences relating to the envisagement of the future, rests nonetheless, in its main outline and content, upon the identical analogy and metaphor that we have seen to underlie Western conceptions of change in time ever since the classical philosophers (Nisbet 2009: 105 my italics)

Metaphors may or may not have remained identical in modern and premodern thought, but ideas of growth or change and the logic of analogical reasoning has on the other hand radically changed. The unit through which we make comparisons is now underpinned by wholly different notions about the natural world as a self-contained entity. Moreover, justificatory strategies have also become very different indeed - scientific rationalism and empiricism have replaced theological or metaphysical disquisitions. Analogies rather than metaphors are central to the modern scientific imagination and the former rather than the latter seems to have proved more influential in modernity. Nisbet masterfully reconstructs the metaphoric use of the ideas of growth and progress and expands on their poetic, theological and even ontological implications therein lies surely a main strength of his work. Yet this is different from the fundamentally logical use of analogies in scientific reasoning and this is not something that figures equally centrally in his historical and philosophical reconstructions. ${ }^{9}$

There are still two additional features of Nisbet's argument on social change that I should like to address. First, Nisbet contends that conflict is an endemic condition of human history. At least since Augustine, which we just saw plays a transitional role in the move from cyclical to linear conceptions of progress, conflict is prevalent both within the city of man and between the city of god and city of man (Nisbet 2009: 86-7). In other words, there are social conflicts between groups of human beings that have different interests, normative conflicts between competing visions of the good life as they are underpinned by rival conceptions of the good life and there are also historical conflicts where material interests and normative views clash (Archer 1995). What we then witness in modernity is the amplification of the centrality of conflict in all aspects of modern social life: conflict becomes now ubiquitous in society; it becomes the engine of history and the only factor that allows for the explanation of social change. ${ }^{10}$

9 The problem of methodological nationalism is again a prime example of this in the social sciences. For the discipline of international relations, this coheres on the question of the so-called 'domestic analogy': whether and to what extent the main features of the international realm can be extrapolated from conditions of social order as they exist at the 'domestic' (i.e. national) level. Thus stated, the problem hangs decidedly on the scientific validity of analogies but has no particular bearing on the use of metaphors. See Bottici (2003), Chernilo (2010), Rolf (2014) and Suganami (1989).

10 In contemporary sociology, Pierre Bourdieu's work offers a prime example of dogmatically asserting the conflictive nature of all social life. For a critique of the 
Secondly, there remains an irresolvable tension between immanent and transcendental aspects of human life: 'Whether for Greek or for Christian, the conception of moral and spiritual decline is inextricably tied up with man's possession of faculties which are crucial to his material and cultural progress on earth' (Nisbet 2009: 94-5). The constitutive problem of modern conceptions of growth is now apparent: history is immanent as a process but transcendental in terms of its telos. The progressive goal of the historical process is deemed cognitively discoverable and practically achievable through human means and human means alone (science and political action being two of these 'practical' realms), but its actual value as a telos, its absolute necessity as the goal of the historical process, requires of transcendental grounds. Modern history does not do away with transcendentalism but rather reintroduces it as the inconsistent justification of immanent social change. Cosmological or theological support remains transcendental at least in the weak sense that it cannot be altered at will or through rational human intervention: if the transcendental justification is missing, social and political action become increasingly emptied of normative support.

II.

The dynamic of continuities and discontinuities that we have discussed so far can be illustrated further by looking into Nisbet's treatment of what is arguably sociology's foundational distinction. Indeed, the question of community, and its relationship to notions of society, is central to his understanding of sociology (Nisbet 1967, 1976). All the ideas of community that he reconstructs in The Social Philosophers - military, political, religious, revolutionary, ecological, and pluralistic - take precedence during particular periods and emphasise particular aspects in the organisation of human life: physical security, particular identities, transcendental values. Yet at the same time they also capture key a-temporal traits of collective life as a whole.

Nisbet takes a relatively conventional view of Tönnies's original formulation of the distinction between community and society; community is closely connected to some normative vision in which human life is supposed to possess 'a high degree of personal intimacy, emotional depth, moral commitment, social cohesion and continuity in time' (Nisbet 1967: 47). ${ }^{11}$ Equally interestingly,

sociological and normative deficits of this position, see Chernilo (2014) and Honneth (1986).

11 Tönnies's (2001: 52) original formulation reads thus: 'Gesellschaft takes as its starting point a group of people who, as in Gemeinschaft, live peacefully alongside one another, but in this case without being essentially united -indeed, on the contrary, they are here essentially detached. In Gemeinschaft they stay together in spite of everything that separates them; in Gesellschaft they remain separate in spite of everything that unites 
however, Nisbet also inverts what had been until then the mainstream proposition that society was more important, both historically and normatively, than community:

Community is not merely a dominating empirical interest of sociologists manifest in studies of kinship, locality, and guild - but a perspective, a methodology, that lights up the study of religion, authority, law, language, personality, and gives rise a new scope of to the age-old problem of organization and disorganization. Sociology, above any other discipline in the century, gave primacy to the concept of the social. The point to be emphasized here, however, is that the referent of "social" was almost invariably the communal. Communitas, not societas with its more impersonal connotations, is the real etymological source of the sociologist's use of the word "social" in his studies of personality, kinship, economy and polity (Nisbet 1967: 56, my italics)

Apart from Tönnies's original formulation, this rendition is also far from Durkheim's (1984) argument in Division of Labour or Reinhard Bendix's (1967) rendition of it in terms of 'tradition' and 'modernity'. As a historical transition, Nisbet associated the movement from Gemeinschaft to Gesellschaft to questions of rapid social change that had in fact become the theoretical backbone to modernisation approaches in the social sciences of the 1950s and 1960s. It was central to modern conceptions of social change because it allowed the study of short to mid-term modernisation policies in 'new nations'. It also lent itself for the study of long-terms patterns of change in 'core nations': '[t]he model of Western Europe and its seeming direction of social change during the past halfdozen centuries - Gemeinschaft to Gesellschaft is, of course, the most popular direction claimed by sociologists - is made the trend of social change for all human civilization and, as countless studies of the so-called modernizing nations suggest, the stereotype for their individual analysis - and also their reconstruction!' (Nisbet 2009: 286). Yet we have seen that Nisbet does not adopt this approach uncritically: while it is arguably the case that a contrast between community and society can often be drawn on the basis of historical transformations, the underlying idea of a unifying process that is able to explain this transition as a causal argument remained highly problematic in his view: '[i]t may indeed be possible to contrast the twentieth century with the twelfth in terms of the familiar logical continuum of Gemeinschaft and Gesellschaft, which we find in one form or other in all of the major sociologists. But differentness does not argue for the existence of a uniting process, endemic, constitutive, genetic, and uniform, called differentiation' (Nisbet 2009: 287). The price for maintaining Gemeinschaft and Gesellschaft as a central sociological theorem is that we avoid its

them (...) Nothing happens in Gesellschaft that is more important for the individual's wider group than it is for himself'. 
reification as an overarching framework for the study of all forms of social change as progressive.

Nisbet then contends that all modern forms of social relations are to be referred back to communal ones: he emphasises the permanence of pre-modern structures of religion, authority and family into modern bureaucratic structures and increasingly individualistic forms of life. The reintroduction of tradition into modernity matters because it brings to the fore the well-known tension that underpins any of rendition of Gemeinschaft and Gesellschaft: whether the distinction is a truly diachronic one and the rise of the latter means the decline of the former, whether both kinds of social relationships can be empirically found at any given time; whether its sociological value lies more at normative level than at the structural one - or indeed whether its sociological appeal depends precisely on the fact that it can be inconsistently applied in all these ways. Also, given his interest in continuities in the history of ideas, it is somehow puzzling that Nisbet did not explicitly spell that the modern sociological version of Gemeinschaft and Gesellschaft follows in the footsteps of the natural law tradition: indirectly, in Augustine's distinction between the city of god and the city of man; directly, in seventeenth-century arguments on the transition from the state of nature to the civil condition from Grotius to Marx via Hobbes Rousseau, Smith, Kant and Hegel (Chernilo 2013). ${ }^{12}$

For an author whose scholarly output is mostly devoted to the history of ideas and the philosophical roots of sociological arguments, Nisbet's The Present Age offers a relatively rare insight of his work as an empirical and political sociologist. In the context of what we have been discussing so far, one striking feature of this book is the extent to which its observations of twentieth-century American society are framed so openly within the argument of an historical transition from community to society. Nisbet's analysis starts with the identification of a single major event that marks a radical historical transition in American history; an event with enough causal strength that was able to trigger the structural transformation of the country as a whole:

The present age in American history begins with the Great War (...) The Great War was the setting of America's entry into modernity - economic, political, social, and cultural. By the 1920s, the country had passed, within mere three years, from the premodern to the distinctly and ineffaceably

12 See, however, passing comments in Nisbet (2009: 89 and 1967: 48). In the latter, he wrongly equates modern natural law theory with bourgeois thinking in way that is not altogether different from the left-Hegelian account that Gillian Rose (2009) offered later in the 1980s. It is worth observing that the last third of Tönnies's Community and Society was actually devoted to the history and contemporary relevance of natural law in modern society. For an in depth analysis of Tönnies's connection to modern natural law theory, see Bond (2013). 
modern (...) the Great War was the occasion of the birth of modernity in the United States (Nisbet 1988: 2, 15, my italics)

This is not isolated hyperbole but similar claims are also made elsewhere in the book and elsewhere. ${ }^{13}$ From its celebrity cult and a newly found fascination with sports to the emergence of a 'scientific-technological elite', from the relaxation of sexual mores to the rise of the bureaucratic 'military-industrial complex' and the later 'fusion of the military and the university', the Great War is said to have put an end to a period of America's history that was based on traditional values. The war unlocked the forces of secularisation, individualisation, technological innovation, bureaucratic expansion, social welfare, economic reform, enfranchisement of women and further promotion of racial equality. America's sociocultural identity as a truly national identity is also said to have started with and thanks to the war; even by 1914, he contends, a 'truly national culture' was still ‘hard to find' in America (Nisbet 1988: 2).

Nisbet is highly critical of the processes that were triggered by these transformations, and in particular of President Wilson's moralisation of foreign policy, which to Nisbet represented the definitive collapse of America's core beliefs in isolationism and domestic democracy. International interventionism is seen as a direct a betrayal of the original 'concerns' and 'design' of the framers of the American constitution (Nisbet 1988: 29, 36) and the decision of playing a decisive role in international affairs was to become America's curse ever since. The highly powerful and increasingly centralised federal state that was required for the war effort to be successful was never to withdraw back to pre-war levels. Rather the opposite, it was to expand even further throughout the New Deal period and beyond. Nisbet assesses these transformations as a form of 'legal and administrative tyranny' that created a new kind of 'democratic absolutism' (Nisbet 1988: 58). There was also unashamed hypocrisy in the way in which the American government opposed, say, Apartheid South Africa whilst at the same time it failed to tackle domestic racism. The price to be paid for these newly established imperialist claims of American foreign policy was nothing short of the erosion of democracy and representative institutions at the domestic level: 'Wilson was pure tragedy, Roosevelt farce' (Nisbet 1988: 30). ${ }^{14}$ With old elites and 'respectable' bourgeois life both on the wane, a new dictatorship of feeling and unrestrained subjectivism is eroding all forms of authority (Nisbet 1988: 121).

13 See Nisbet (1988: 5, 42, 140; 1986: 133). The more general argument has of course often been made that war is a major factor in effectuating social change, so what happened in this case was the more or less predictable result of an unprecedented war effort that involved all areas of society. See, recently, Mann (2012)

14 Mainstream social science in America was, on the contrary, fully in favour of an increasingly powerful state and American intervention in the World Wars (Nisbet 1988: 51, Gerhardt 2002, Shils 1980). 
This somewhat uncritical application of Gemeinschaft and Gesellschaft is not completely surprising at least in the sense that it brings home a central intuition of Nisbet work we discussed above; namely, that sociology's explicit interest in societal developments is in fact dependent on a deeper interest in transformations at the level of community - local and personal bonds, the traditional authority of family and religion. The sociological interest in the formation of modern society lies in whether and how it can re-invigorate forms of communal life - and, if not, in understanding what will be the consequences of such failure. In his depiction of the transformations of American society in the first half of the past century, Nisbet the empirical sociologist comes together with Nisbet the conservative political commentator.

But Nisbet's analysis of twentieth-century American history sits somewhat uneasily with the conclusions of his own work as an intellectual historian. Decay rather than progress is now central to his portrayal of current American society and to that extent he remains within consistent with his previous critique of the ubiquity of ideas of progress in contemporary society. At the same time, his empirical account of social change in America is more problematic because it depends on the identification of a single factor - American involvement in World War I - that is then used as the master key that unlocked transformations at all levels of social and political life. This analytical move appears to contradict Nisbet's own critique of the spurious logic of causal arguments in scientific rhetoric. While not progressive in a normative sense, his portrayal of American society is one of linear social change as we reconstructed it above: natural, directional, immanent, continuous, necessary and uniform.

III.

In this last section I would briefly like to compare some of the arguments we have encountered so far with others that were available to Nisbet had he looked in a different direction. As I compare them with some of the arguments that were advanced by Karl Löwith and Leo Strauss, my goal for this last section is to unpack some of the wider implications of Nisbet's arguments above. ${ }^{15}$

First written in 1949, Karl Löwith's main goal in Meaning in History was to question a key assumption of the modernist historical imagination; namely, to have mistaken the radicality of its attempted critique of religion as expression of its alleged success in doing so. What has since become known as Löwith's secularisation thesis is based on a type of historical and philosophical reconstruction that is not altogether different from that of Nisbet. Löwith also takes a long durée approach to intellectual history and contends that ancient

15 This last section draws on my discussion of Löwith, Strauss and Voegelin's views on modernity and the social sciences (Chernilo 2013: 39-70). For reasons of space, I do not deal with Voegelin's writings here. 
philosophy based on cyclical cosmologies, religious doctrines that believe in transcendental salvation, and enlightenment social and political thought with their secular ideas of immanent progress, effectively exhaust our human options for thinking the meaning of life through history. He argues that 'neither a providential design nor a natural law of progressive development is discernible in the tragic human comedy of all times' (Löwith 1964: v), and yet the most crucial intellectual conviction of modern times is precisely a belief, which is inconsistent in terms of the rationality of its own intellectual standards, in the purposeful character of history:

We of today, concerned with the unity of universal history and with its progress toward an ultimate goal or at least toward a 'better world', are still in the line of prophetic and messianic monotheism, we are still Jews and Christians, however little we may think of ourselves in those terms (...) We are neither ancient ancients nor ancient Christians, but moderns - that is, a more or less inconsistent compound of both traditions. (...) It seems as if the two great conceptions of antiquity and Christianity, cyclic motion and eschatological direction, have exhausted the basic approaches to the understanding of history. Even the most recent approaches at an interpretation of history are nothing else but variations of these two principles or a mixture of both of them (Löwith 1964: 19 my italics)

In Meaning in History, Löwith covers similar materials to those discussed by Nisbet, but the book's structure is atypical. Its first substantive chapter focuses on the work of Jacob Burckhardt (1818-1897) and Löwith then moves backwards in history to end with the bible, while in the process he revisits, always in inverse chronological order, various conceptions of history in, among others, Marx, Hegel, Comte, Voltaire and Augustine. Löwith's book then begins its historical assessment at that point in time in which teleological conceptions of history are already at an end; all three notions of history - cyclical, salvationist and progressive - have become inadequate to give history meaning under contemporary conditions. Nisbet and Löwith equally understand that modern social science is not completely exempt from the pressures of having to offer some normative vision of current affairs - and more often than not it has allied itself with progressive ones. The scientific vocation of the social sciences does not altogether cancel the need for normative insight, and for Löwith the modern sociologist has nowhere safe to go as no idea of history can nowadays provide consistent and meaningful answers to existential questions: what constitutes us as humans and our shared humanity, what makes a society fair, is it possible (and how) to achieve firm normative standards, does life have an ulterior meaning and, if so, where does it lie and how do we get to know about it. ${ }^{16}$ In

16 Already in the early 1930s, Löwith had argued that a dual sociological (i.e. the study of modern capitalism) and philosophical (i.e. what makes life 'human') concern constituted 
terms of the integrity of its normative foundations, therefore, modernity is not only inconsistent but in fact compares poorly with previous epochs: because it 'has not made up its mind whether it should be Christian or pagan. It sees with one eye of faith and one of reason. Hence its vision is necessarily dim in comparison with either Greek or biblical thinking' (Löwith 1964: 207).

We have seen that also for Nisbet the main problem with modern conceptions of progress is that immanent processes and transcendental values grow increasingly incompatible. In Löwith's case, the methodological challenge is how he can justify his own historical reconstruction that leads necessarily to a critique of progress without resorting to the kind of developmentalism he had criticised. Löwith does not ultimately succeed in making this argument work - not least because he does not pay enough attention to the difference between strictly secular and eschatological goals (Blumenberg 1983). For his part, Nisbet fully accepts the difference between Christian eschatology and modern developmentalism and uses it the major distinction that gives rise to strictly modern conceptions of social change. Yet the price Nisbet paid for this is the inability to account for his own normative position in terms of historical or empirical analysis. As we saw in the previous section, Nisbet's 'conservative' assessment of contemporary American society remain at odds with his work as intellectual historian because his argument on the Great War that marks the transition from community to society offers a one-sided view of the historical process as moving unequivocally towards a decaying condition. Löwith was less of a political thinker in this regard and he systematically refrained from drawing normative consequences from his arguments and even surrendered to some existential despair: no consistent normative outlook is ultimately possible within modernity (Löwith 1966, 1995).

Although there are some passing references to Leo Strauss in Nisbet's (2009: 80) work, these concentrate on specific aspects of his interpretation of the Greek idea of nature rather than on Strauss's more general arguments on modernity and the social sciences. Yet there is a great deal of compatibility between the two writers: Strauss's critique of the modernist bias in contemporary social science is instructive because he simultaneously seeks to recover a sense of wisdom that is to be found in the philosophical tradition and accepts that modern conditions make us question whether this recovery is at all possible. With the traumatic experience of the Jewish Holocaust in mind, Strauss contends that mainstream social science has fallen below the critical threshold once achieved by its philosophical predecessors:

the greatness of Weber and Marx's work. He thus describes them as 'philosophical sociologists' (Löwith 1993: 48). 
After the experience of our generation, the burden of proof would seem to rest on those who assert rather than on those who deny that we have progressed beyond the classics. And even if it were true that we could understand the classics better than they understood themselves, we could become certain of our superiority only after understanding them exactly as they understood themselves. Otherwise we might mistake our superiority to our notion of the classics for superiority of the classics (Strauss 2004: 55)

Not far from Löwith's argument, Strauss (1974) also criticised the reductionist self-understanding of modernity as a self-positing historical period. Modernity's current crisis was marked for Strauss by its descent into barbarism in World War II and the difficulties associated in reconstituting normative standards in its aftermath. He argued that one clear expression of this was the contemporary transition from substantive conceptions of progress that were actually able orient political action to a mere belief in the idea progress that can be upheld or discarded at will (Strauss 1997: 94-100). A belief in progress is a contradiction in terms, however, as the need to critically engage in its reconstruction is already an expression of its substantive defeat in terms of its quasi-transcendental ability to orient political action.

Strauss opposed the positivistic mainstream of current social science but did not reject it tout court. The main problem the social sciences face is that they have lost sight of the centrality of the normative in social life, the fact that reflecting on normative questions is now wrongly regarded as a task for which neither science nor philosophy are adequately equipped: 'it is this difficulty which is at the bottom of what in the social sciences is called the "value problem": that philosophy or science, however you might call it, is incapable of giving an account of its own necessity' (Strauss 1997: 131). Yet positivism turns shortcomings into virtues and thus rejoices in our inability to speak about fundamental normative problems. Presented as 'value questions', normative problems are predefined as fundamentally subjective and therefore irrational: as no rational account of one's position can be ever be given, we merely have to opt for one or another value and let others do the same. But this standpoint is not restricted to radical positivists and has in fact become mainstream through a wholly relativistic interpretation of Weber's reflections on the polytheism of values (Strauss 1974: 36-78). This was not Weber's position, he contends, but its more important consequence is that it has contemporary social science on completely the wrong track:

A social science that cannot speak of tyranny with the same confidence with which medicine speaks, for example, of cancer, cannot understand social phenomena as they are. It is therefore not scientific. Present-day social science finds itself in this condition. If it is true that present-day social science is the inevitable result of modern social science and of modern philosophy, one is 
forced to think of the restoration of classical social science (Strauss 2004: 49, my italics) ${ }^{17}$

Serious intellectual endeavour is then defined by its attempts at understanding how human beings are able to live their life in common. The modern condition makes our awareness of this challenge more acute but not fundamentally different from previous historical periods. Strauss would arguably have accepted neither Löwith's withdrawal from the world nor Nisbet's isolationist conservatism. In turn, Nisbet the sociologist would have been deeply sceptical of Strauss's attempt to recover a sense of classical wisdom and virtue that has become definitively lost in mass and bureaucratic society.

Rather, Nisbet was of the view that science does contribute to make apparent the definitive aporia of modern civilisation: our existential human need for finding order in the natural cosmos as well as inside social life itself is bound to be disappointed as it clashes with the inevitable inadequacy of our representations of such sense of order and the justifications with which we try to account for these spheres. While cosmological ideas are key in terms of our fundamental human needs for order, self-expression and sense of transcendence, they are also fundamentally insufficient as the rational underpinnings of the modern scientific outlook: '[p]rophecy, in its temporal as well as moral connotation, is probably an inalienable part of the human condition and of human aspiration' (Nisbet 2009: 246). There is no readily available solution to our conflicting needs for a transcendental sense of order and for having to rationally enquiry whether that order is legitimate and how it has come about: ' $[\mathrm{t}] \mathrm{o}$ believe that the vast, plural, and infinitely particular history of mankind can somehow be worked into ordered frameworks of either cyclical or linear development, that somehow progress (or degeneration) can be made endemic processes, fixed parts of reality, calls plainly for a gigantic leap of faith (...) But it is exceedingly doubtful that we could live, most of us, without such faith' (Nisbet 2009: 223). Modern Western civilisation has no problem in finding empirical instances of progress - we are taller and live much longer than our predecessors, technological innovations

17 Compare the similar underlying sensibility that inspires Hannah Arendt's (1953: 79) reply to Eric Voegelin's review of her Origins of Totalitarianism: '[t]o describe the concentration camps sine ira et studio is not to be "objective," but to condone them; and such condoning cannot be changed by condemnation which the author may feel duty bound to add but which remains unrelated to the description itself. When I used the image of hell, I did not mean this allegorically but literally (...) I think that a description of the camps as Hell on earth is more "objective," that is, more adequate to their essence than statements of a purely sociological or psychological nature'. In his 1964 lecture course on Hitler and the Germans, Voegelin (1999: 64-5, 234-5) does refer to Arendt's work, but to Eichmann in Jerusalem rather than to Origins of Totalitarianism. On Arendt's understanding of Totalitarianism, see Fine (2001:100-121). On her critique of sociology, see Baehr (2010). 
allow us to do things that were unimaginable only a few generations ago - but improvements of this kind cannot be consistently put together and turned into a progressive cosmology that touches on questions about the meaning of human life. Nisbet did not locate himself above or beyond this conflict but battled with it throughout his work.

\section{$\underline{\text { References }}$}

Archer, M. S. (1995) Realist social theory. The morphogentic approach, Cambridge: Cambridge University Press.

Arendt, H. (1953) 'The origins of totalitarianism - A reply', Review of Politics 15 (1): 76-84.

Aron, R. (1972) Progress and Disillusion, Harmondsworth: Penguin.

Bendix, R. (1967) 'Tradition and modernity reconsidered', Comparative Studies in Society and History 9 (3): 292-346.

Baehr, P. (2010) Hannah Arendt, totalitarianism and the social sciences, California: Stanford University Press.

Bendix, R. (1970) Embattled reason. Essays on social knowledge, New York: Oxford University Press.

Blumenberg, H. (1983) The legitimacy of the modern age, Massachusetts: MIT Press.

Boltanski, L. (2013) The Foetal condition. A sociology of engendering and abortion, Cambridge: Polity Press.

Bond, N. (2013) Ferdinand Tönnies' 'Community and Society'. Social theory and political philosophy between enlightened liberal individualism and transfigured community, Berlin: LIT.

Bottici, C. (2003) 'The domestic analogy and the Kantian project of Perpetual Peace', The Journal of Political Philosophy 11 (4): 392-410.

Bottomore, T. and Nisbet, R. (eds.) (1978) A history of sociological analysis, London: Heinemann.

Chernilo, D. (2007) A social theory of the nation-state: The political forms of modernity beyond methodological nationalism, London: Routledge. 
Chernilo, D. (2010) 'Methodological nationalism and the domestic analogy: Classical resources for their critique', Cambridge Review of International Affairs 23 (1): $87-106$.

Chernilo, D. (2011) 'The critique of methodological nationalism: Theory and History', Thesis Eleven 106 (1): 98-117.

Chernilo, D. (2013) The natural law foundations of modern social theory: A quest for universalism, Cambridge: Cambridge University Press.

Chernilo, D. (2014) 'The idea of philosophical sociology', British Journal of Sociology 65 (2): 338-357.

Durkheim, E. (1984) The division of labour in society, London: Macmillan.

Fine, R. (2001) Political Investigations, London: Routledge.

Gerhardt, U. (2002) Talcott Parsons. An intellectual biography, Cambridge:

Cambridge University Press.

Ginsberg, M. (1965) On justice in society, London: Penguin.

Hochstrasser, T. (2000) Natural law theories in the early enlightenment, Cambridge: Cambridge University Press.

Honneth, A. (1986) 'The fragmented world of symbolic forms: Reflections on Pierre Bourdieu's sociology of culture', Theory, Culture and Society 3 (3): 55-66.

Löwith, K. (1993) Max Weber and Karl Marx, London: Routledge.

Löwith, K. (1964) Meaning in history, Chicago: The University of Chicago Press.

Löwith, K. (1966) Nature, history and existentialism, Evanston: Northwestern University Press.

Löwith, K. (1995) Martin Heidegger and European nihilism, New York: Columbia University Press.

Luhmann, N. (1977) 'Generalized media and the problem of contingency' in Loubser, J., Baum, R., Effrat, A. and Lidz, V. (eds.) Explorations in the general theory in social science. Essays in honour of Talcott Parsons, vol. two, New York: The Free Press.

Mann, M. (2012) The sources of social power vol. 3: Global empires and revolution, 1890-1945, New York: Cambridge University Press. 
Merton, R. (1968) Social theory and social structure, New York: The Free Press.

Nisbet, R. (1967) The sociological tradition, London: Heinemann.

Nisbet, R. (1976) The social philosophers, Frogmore: Paladin.

Nisbet, R. (1977) Sociology as an art form, Oxford: Oxford University Press.

Nisbet, R. (1980) History of the idea of progress, New York: Basic Books.

Nisbet, R. (1986) The making of modern society, New York: New York University Press.

Nisbet, R. (1988) The present age. Progress and anarchy in modern America, Indianapolis: The Liberty Fund.

Nisbet, R. (2009) Metaphor and history. The Western idea of social development, New Brunswick: Transaction.

Parsons, T. (1967) 'Evolutionary Universals in Society' in Parsons, T. Sociological Theory and Modern Society, New York: The Free Press.

Parsons, T. (1971) The system of modern societies, Englewood Cliffs: Prentice-Hall.

Rolf, J. N. (2014) 'The state of nature analogy in International Relations theory', International Relations 28 (2): 159-182.

Rose, G. (2009) Hegel contra sociology, London: Verso.

Shils, E. (1980) The calling of sociology and other essays in the pursuit of learning, Chicago: The University of Chicago Press.

Strauss, L. (1974) Natural right and history, Chicago: The University of Chicago Press.

Strauss, L. (1997) Jewish philosophy and the crisis of philosophy, Albany: State University of New York Press.

Strauss, L. (2004) 'Restatement on Xenophon's Hiero', in Emberley, P. and Cooper, B. (eds.) Faith and political philosophy. The correspondence between Leo Strauss and Eric Voegelin, 1934-1964, Columbia: University of Missouri Press. 
Suganami, H. (1989) The domestic analogy and world order proposals, Cambridge: Cambridge University Press.

Tönnies, F. (2001) Community and civil society, Cambridge: Cambridge University Press.

Toulmin, S. (1990) Cosmopolis. The hidden agenda of modernity. Chicago: The University of Chicago Press.

Voegelin, E. (1999) 'Hitler and the Germans', in The collected works of Eric Voegelin Vol.31, Columbia: University of Missouri Press.

Voegelin, E. (2000) 'The new science of politics', in The collected works of Eric Voegelin Vol. 5, Columbia: University of Missouri Press. 